\section{CHLORINE AS A PREVENTIVE OF INFLUENZA ${ }^{1}$ By Harrison Hale \\ Universtiy of Arkansas, Fayettevilie, Arkansas \\ Received Apri1 1, 1920}

By order of the City Board of Health the city schools and churches of Fayetteville, Arkansas, were closed February I, 1920. It was decided by the authorities of the state university not to suspend university work. Conditions seemed unusually favorable to try the use of chlorine as a preventive of influenza, an indirect report of its preventive influence in the case of employees in a certain government plant during 1918 having been received.

Accordingly one of the smaller chemical laboratories was taken for this work, and daily tests were begun February 2 with volunteers from the college community. The room used was $22 \times$ I5 $\times$ I2 $\mathrm{ft}$., and the chlorine was generated by the usual laboratory method of treating manganese dioxide and sodium chloride with sulfuric acid, using 25 to $50 \mathrm{~g}$, of salt in each generator. The amount of chlorine in the air after mixture by an electric fan placed behind the beaker of water through which it was passed to remove excess of hydrochloric acid, varied widely. This showed 43 to 273 parts per million by volume, or $0.01 \mathrm{I}-0.068$ per cent by weight as determined by titration with sodium thiosulfate of iodine, liberated when a known volume of ait was bubbled through a potassium iodide solution.

This variation was due to differences in the speed at which the gas was liberated and to its removal from the room, through the frequent opening and closing of the door, and by being carried away in the lungs and clothing of those treated. It is also quite certain that the chlorine content at different heights was not the same.

Into this room those receiving treatment came for a period of 5 min., either two or three at the same time, or as many as twenty. Not all took this treatment each day of the eight days upon which it was given. Altogether about 800 treatments were given to 184 different individuals. None of these de-

1 Presented at the 59th Meeting of the American Chemical Society, St. Louis, Mo., April 12 to 16,1920 . veloped influenza except one, who began to feel sick within a few hours after his first treatment. It seems certain his case had developed before taking the treatment.

Up to February 9 the actual number of cases reported in the town approximated 150 , or about one in each 40 inhabitants, but one-third of these developed before the treatments began.

Of the 184 taking the treatment more than two-thirds had had influenza in the attack of a year or more ago. This 184 included six or eight children and several faculty members and was not solely confined to those of college-student age. The nurse who cared for patients at the university infirmary was one of those taking the treatment, and she escaped the disease.

The crowding of a hundred people daily into a small room within a period of the few hours during which treatments were given might have been a source of increased number of cases except for the germicidal effect of the chlorine. Bacterial plates exposed in this room for Io min. were practically sterile. Similar results, however, were obtained in another laboratory in the same building.

Perhaps two facts should be clearly stated to forestall two false impressions which we encountered: First, the chlorine does not cure after the case is well developed. A few students claimed that it did for them, but their reports are given little credence, as it probably only cleared the nasal passages, and they did not have influenza to begin with; and second, it does not grant future immunity, beyond a very short time.

Our results tend to show that chlorine does act as a preventive of influenza, but the rapid improvement in the local situation, which led to the raising of the quarantine on February 14, prevented their being conclusive. So far as we know this is the first use of chlorine as an influenza preventive in a college community and our results agree with those from chlorine plants as reported by Baskerville ${ }^{1}$ a year ago.

Obviously the same treatment could be given in the home, using chloride of lime as the source of the chlorine. There seems to be no danger of causing serious after-effects from too much chlorine, with the amounts we used.

1 "Certain War Gases and Health," Science, 50 (1919), 50; "Chlorine and Influenza," THIS JournaL, 12 (1920), 293.

\title{
CHEMICAL READING COURSES ${ }^{1}$
}

Prepared by the Committee on the Preparation of a Recommended List of Chemical Texts for Libraries W. A. HAMOR, Chairman, L. C. NEWELL, A. M. PATYERSON, W. SEGERBLOM

(Concluded from the July issue)

\section{ORGANIC AND BIOLOGICAL CHEMISTRY ${ }^{2}$}

"THE DAY" OF THE CHEMIST IS HERE!

What of business in America after the war? Opinion is divided between those who are optimistic and see only continued prosperity, and those who think a period of depression must be weathered. But there is one man who seems sure of a job, and that is the chemist. There is, in fact, not enough of him to supply the demand. The country opened its eyes to him during the war, and now he is needed to solve the economic utilization of our vast resources, the elimination of wastes, improved sanitation, and increase in foodstuffs and clothing.

But it is trained chemists that are wanted. There must be thorough preparation for the profession, and those who are prepared must keep mentally alert and in touch with advances in the science.

FIGHTING WITH ORGANIC COMPOUNDS

America would have been at a fatal disadvantage in the World War without her organic chemists. First, they were called on to make good the deficiency in dyes, pharmaceutical products and other items, and new factories sprang up like dream castles. Then came demands for TNT, mustard gas, and other organic tools of war. Truly a wonderful field of knowledge! One of the best known introductions to the subject

1 Presented to the Council at the 58th Meeting of the American Chemical Society, Philadelphia, Pa, September 2, 1919.

2 By Dr. Austin M. Patterson. is Perkin and Kipping's "Organic Chemistry" (New edition; Lippincott, I $197 ; \$ 2.25^{1}$ ). Another clear and interesting book is "The Principles of Organic Chemistry" by J. F. Norris (McGraw-Hill, 1912; \$2.50).

\section{HOW THEY ARE MADE}

Less than a century ago it was still supposed that organic compounds could be synthesized only by the "vital force" existing in plants and animals, and the artificial preparation of urea by Wöhler in 1828 from inorganic materials is therefore considered an epoch in the history of the science. Since then many other organic compounds have been so made, and a whole host of transformations discovered which can now be carried out by any one with the proper training. F. J. Moore's "Experiments in Organic Chemistry" (Wiley; \$o.5o) is a widely used little manual requiring only simple equipment. Gattermann's "Practical Methods of Organic Chemistry" is a well tried standard handbook for organic preparations which is available in an English translation (MacMillan, I9I6; \$I.75). A HAPPY COMBINATION

The great success attained by Germany in a chemical way was not due, as people now realize, to any inherent superiority in her men, but to the direct encouragement of research by the government, and the close relation between her universities and her manufacturers, all of which resulted in a splendid organization. Pure science and industry have much to gain from intimate association. It therefore seems good fortune to find a book

1 Prices quoted throughout are as of the date of preparation of this report and are printed simply to serve as a guide to the general trend of prices 